\title{
Performance Study On An Intermediate Temperature Solid Oxide Fuel Cell (IT-SOFT) Fabricated By Dry Pressing Method
}

\author{
${ }^{1}$ A. Rifau, ${ }^{1}$ Z. Zainal, ${ }^{1}$ D. Mutharasu, ${ }^{2}$ A. Fauzi, ${ }^{3}$ Y. Kiros, ${ }^{3}$ B. Zhu, ${ }^{3}$ R. Zanzi \\ ${ }^{1}$ School of Mechanical Engineering, University of Science Malaysia (USM) \\ 14300 Nibong Tebal, Pulau Pinang, Malaysia \\ ${ }^{2}$ School of Materials, University of Science Malaysia (USM) \\ 14300 Nibong Tebal, Pulau Pinang, Malaysia \\ ${ }^{3}$ Department of Chemical Engineering \& Technology, Chemical Reaction Engineering \\ KTH, Royal Institute of Technology, 10044 Stockholm, Sweden
}

\begin{abstract}
An intermediate temperature solid oxide fuel cell (IT-SOFC) has been developed by using the dry pressing method. Widely studied materials were used for anode and cathode and SDC based electrolyte was used in this study. The cells were fabricated by dry-pressed at different pressures using a die without any binding material, a known amount of three electrode materials in powder form were pressed together and a nickel mesh was used as current collector. The test area of the fabricated cells was $0.785 \mathrm{~cm}^{2}$. The experiments were conducted using $\mathrm{H}_{2}$ as fuel and compressed air as oxidant. The cells were tested under different operating temperatures with varying fabrication parameters. The fabricated cells recorded an open cell voltage (OCV) of $765 \mathrm{mV}$ while operating at $560^{\circ} \mathrm{C}$. The maximum current density obtained was $726 \mathrm{~mA} / \mathrm{cm}^{2}$ and with a power density of $193 \mathrm{~mW} / \mathrm{cm}^{2}$
\end{abstract}

Keywords: Current Density, Power Density, SDC, Cell operating temperature

\section{INTRODUCTION}

Research focus has been to solid oxide fuel cells recently due to the increase in the petroleum fuel price and also because of the call for environmental pollutions. Solid Oxide Fuel Cells (SOFC) are a part of the research due to its advantages in accepting wider range of gases as fuel and also for that nature that it's all solid based. Different research has been going on in the area of optimization and fabrication. The main drawback of the SOFCs is its high temperature operation in the range of $1000^{\circ} \mathrm{C}$, resulting in material constraints for both electrode and cell construction. Recent focus is on reducing the operating temperature as it will give several advantages mainly giving a wider choice of low-cost and high performance materials with a higher stability which will reduce the degradation, increased freedom for structural design etc. [1-4]. Interestingly the trend of research has been following the renewable and sustainable energy means with lower if not null impact on the environment.

Researchers are studying SOFC using gas derived from gasification using wood or coal [5-7]. Sylvia et al studied the impact of wood derived gasification gases, which consists of $\mathrm{H}_{2}, \mathrm{~N}_{2}, \mathrm{CO}, \mathrm{CO}_{2}$ and $\mathrm{CH}_{4}$ on an IT-SOFC [7]. Zhu discusses the advantages of IT-SOFC for tractionary applications. The ceria-based composite material, which was used shows a super ionic conductivity at $400-600^{\circ} \mathrm{C}$ operated between $300-1500 \mathrm{~mA} / \mathrm{cm}^{2}$ with a power density of $200-700 \mathrm{~mW} / \mathrm{cm}^{2}[8]$. An SOFC using ceria-carbonate composite electrolyte have demonstrated 0.15-0.25 $\mathrm{W} / \mathrm{cm}^{2}$ at a very low temperature in the range of 320$400^{\circ} \mathrm{C}$ and ceria-lanthanum oxide composites show a better performance of $0.35-0.66 \mathrm{~W} / \mathrm{cm}^{2}$ while operating at a temperature of $500-600^{\circ} \mathrm{C}$ [9]. Different fabrication techniques have been carried out by researchers to get better performances in SOFC. Hatae et al studied the i$\mathrm{V}$ and i-P characteristics for three separate single cell samples with multi-layered anode, recording the maximum power density at $0.32 \mathrm{~W} / \mathrm{cm}^{2}$ which operated at $800^{\circ} \mathrm{C}$ with 10 layers of anode [10]. Kim et al in his research fabricated an anode-supported electrolyte thin film SOFC for intermediate temperature showing a performance of $550 \mathrm{~mW} / \mathrm{cm}^{2}$ at $850^{\circ} \mathrm{C}$ [11].

Different fabrication techniques have been followed in order to get the most cost-effective method by different researchers [12-15]. The potential of screen-printing technology to manufacture planar SOFC devices were investigated by Rotureau et al [14], who showed a power density of $1.2 \mathrm{~mW} / \mathrm{cm}^{2}$ without

Corresponding Author: $\quad$ Z. Zainal, School of Mechanical Engineering, University of Science Malaysia (USM) 14300 Nibong Tebal, Pulau Pinang, Malaysia 
optimizing the performance of the cell at $800^{\circ} \mathrm{C}$ and Xia et al [15] fabricated SOFC by a simple and cost effective dry-pressing process which was tested between $400-650^{\circ} \mathrm{C}$ obtaining a maximum of $145 \mathrm{~mW} / \mathrm{cm}^{2}$ and $400 \mathrm{~mW} / \mathrm{cm}^{2}$ at 500 and $600^{\circ} \mathrm{C}$ respectively [15]. In this paper studies on an IT-SOFC, which was fabricated by dry-pressing method has been conducted. Results are presented by operating the cells fabricated with varying compaction pressure.

\section{MATERIALS AND METHODS}

The electrolyte material used for the preparation of the electrode was based on Samariadoped-ceria (SDC), synthesized using cerium nitrate hexahydrate and samarium nitrate hexahydrate [16] in $1 \mathrm{M}$ solutions. The solutions were mixed in the desired stoichiometric amounts such as $20-\mathrm{mol} \% \mathrm{Sm}$ in Ce. The anode is usually nickel, but a new type of alloy material based on $\mathrm{Ni}-\mathrm{Cu}-\mathrm{Fe}(70-20-10 \mathrm{~mol} \%)$ was prepared to characterize the activity of each anode. The cathode was either composed of lithiated nickel oxide or was based on barium-strontium-cobalt-iron oxide (BSCF) prepared according to the report by Shao et al [17]. The electrolyte was mixed in 1:1 volume ratio with respective anode and cathode materials.

Cells were fabricated by dry pressing method using a hardened metal mold to press the electrode parts (anode, electrolyte and cathode) one above the other, where the electrolyte is sandwiched between the anode and cathode. The pressed electrode measures $1.2 \mathrm{~cm}$ in diameter and thicknesses were varied both by changing the compaction pressure and the weight of the ingoing electrode materials to the mold. Each electrode material was pressed separately at a lower pressure to compact it before the other part (electrode powder) was added to the mold, preventing the uniform layers from each part. The compaction pressures were varied to get the effect of cell formulation and adhesiveness. Following compaction, the cells were placed in a temperaturecontrolled oven for 1 hour at various temperatures. This technique, which has been widely used in laboratories and industries to make parts thicker than $0.5 \mathrm{~mm}$ is simple, very cost-effective and reproducible [15].

Before test performances, SOFCs' constituents were characterized using conventional techniques using $X$-ray diffraction, SEM and EDX. Polarization measurements were recorded by a data logger (SR630 by Stamford Research Systems) after loading the cells using a variable resistor.

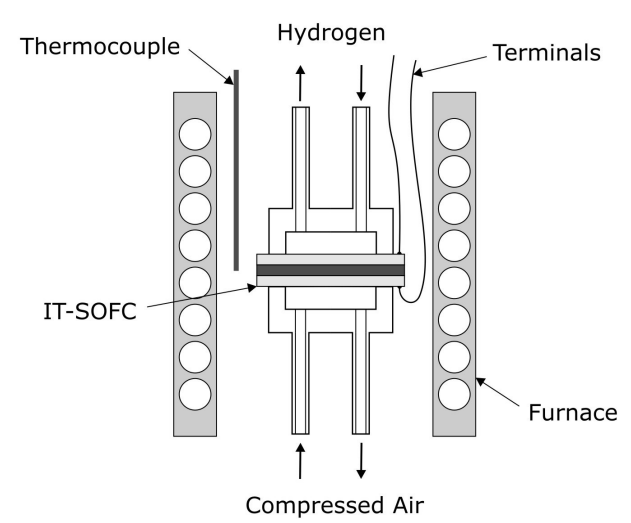

Fig. 1. Schematic of experimental setup

A test bench consisting of two gas chambers was developed using stainless steel (SS304) as shown in Fig. 1. The flow rate of hydrogen and compressed air supplied to the cell chambers were controlled using flowmeters (A-03267-09 for air and A-03267-02 for hydrogen, Cole-Palmer). The contact of cell with the holder was made using silver conductive paint (1863593 by RS Components). A temperature controlled furnace is used to maintain the cell temperature with a maximum working temperature of $1200^{\circ} \mathrm{C}$.

\section{RESULTS AND DISCUSSION}

\section{Material characterization}

Fig. 2 shows the cross-sectional SEM micrographs of cell components. Thicknesses of the electrodes were about $440 \mu \mathrm{m}, 400 \mu \mathrm{m}$ and $440 \mu \mathrm{m}$ for anode, electrolyte and cathode respectively. The particle size varies from 0.5 to $3 \mu \mathrm{m}$ for the anode and 1 to $3 \mu \mathrm{m}$ for the electrolyte. Some small voids were observed under the SEM investigation but no pinholes or cracks were observed on the electrodes.

\section{Cell performance}

Fig. 3 shows the $I-V$ curves and the corresponding power densities at different cell operating temperatures as fabricated at different compaction pressures of 100,150 and $200 \mathrm{~kg} / \mathrm{cm}^{2}$ for (a), (b) and (c) respectively. As seen from the figures it is observed that the best cell performance was for the cells fabricated with the compaction pressure of $150 \mathrm{~kg} / \mathrm{cm} 2$ (Fig. 3b). This indicates that this compaction pressure is apposite for hydrogen permeation and reaction through the anode compartment as well as the optimum conditions for the cell performance. The cell provided the maximum voltage of $840 \mathrm{mV}$ while operating at $560^{\circ} \mathrm{C}$ whereas the highest power density for this cell was recorded when it was operating at $680^{\circ} \mathrm{C}$ with an OCV of $675 \mathrm{mV}$ and a power density $195 \mathrm{~mW} / \mathrm{cm}^{2}$ at a current density of $700 \mathrm{~mA} / \mathrm{cm}^{2}$. 

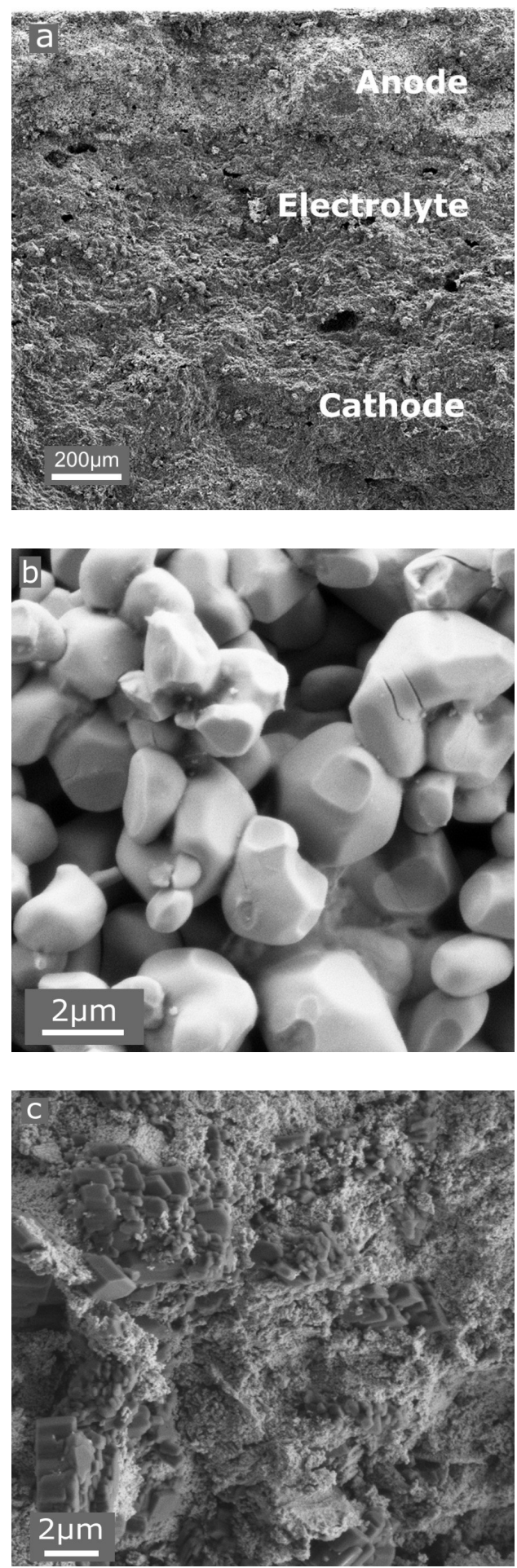

Fig. 2: Cross-sectional SEM micrographs of (a) a single cell, (b) porous $\mathrm{Ni}$ anode and (c) dense SDC electrolyte
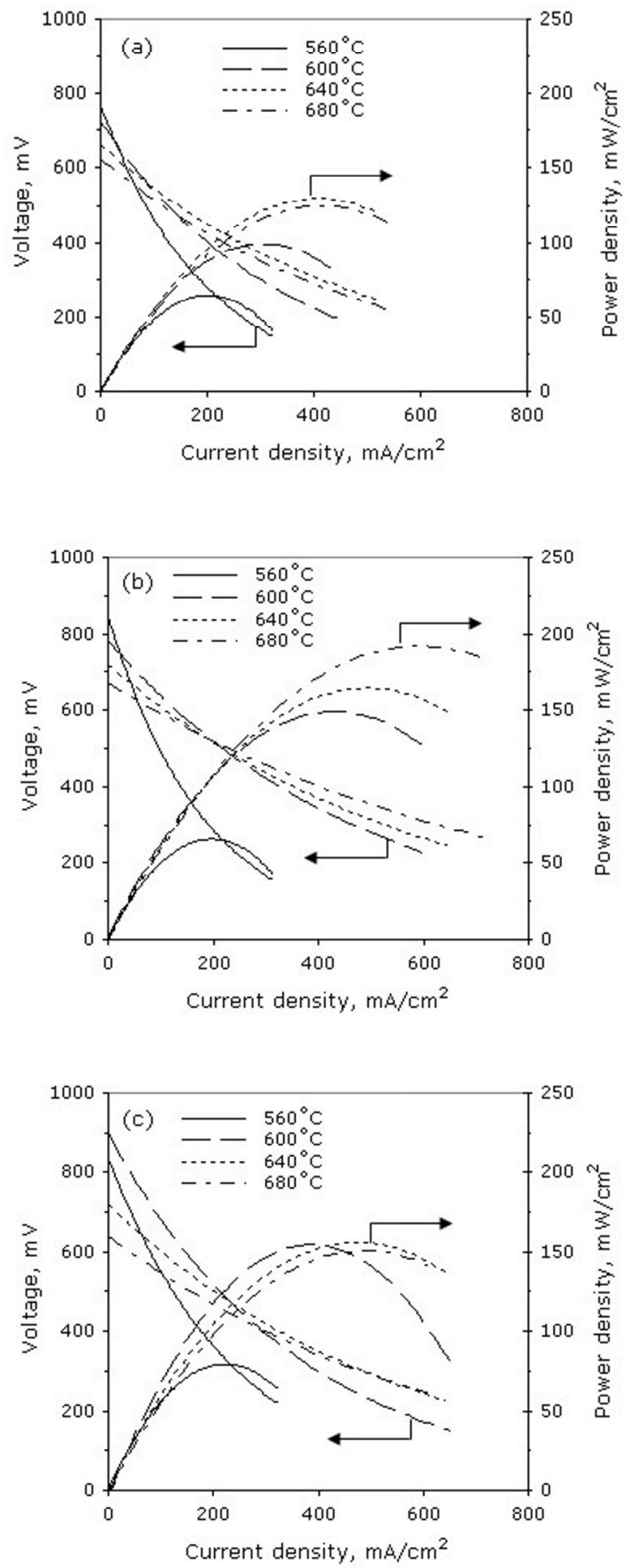

Fig. 3. I-V curves and corresponding power densities at different cell operating temperatures fabricated with (a) $100 \mathrm{~kg} / \mathrm{cm}^{2}$, (b) $150 \mathrm{~kg} / \mathrm{cm}^{2}$ and (c) $200 \mathrm{~kg} / \mathrm{cm}^{2}$ compactions pressures 


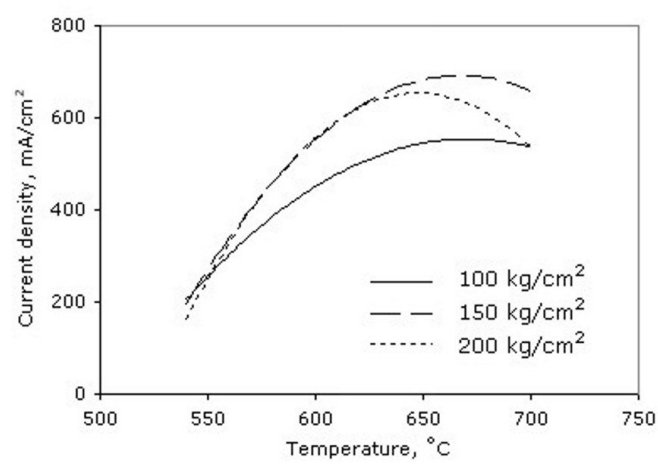

Fig. 4: Maximum current densities for different compaction pressure at varying cell operating temperatures.

The maximum power density was achieved by the cell fabricated with $150 \mathrm{~kg} / \mathrm{cm}^{2}$ compaction pressure operating at $675^{\circ} \mathrm{C}$ followed by the cell fabricated with $200 \mathrm{~kg} / \mathrm{cm}^{2}$ compaction pressure as shown from the comparative studies of the curves in Fig. 4.

At lower temperatures the cells were

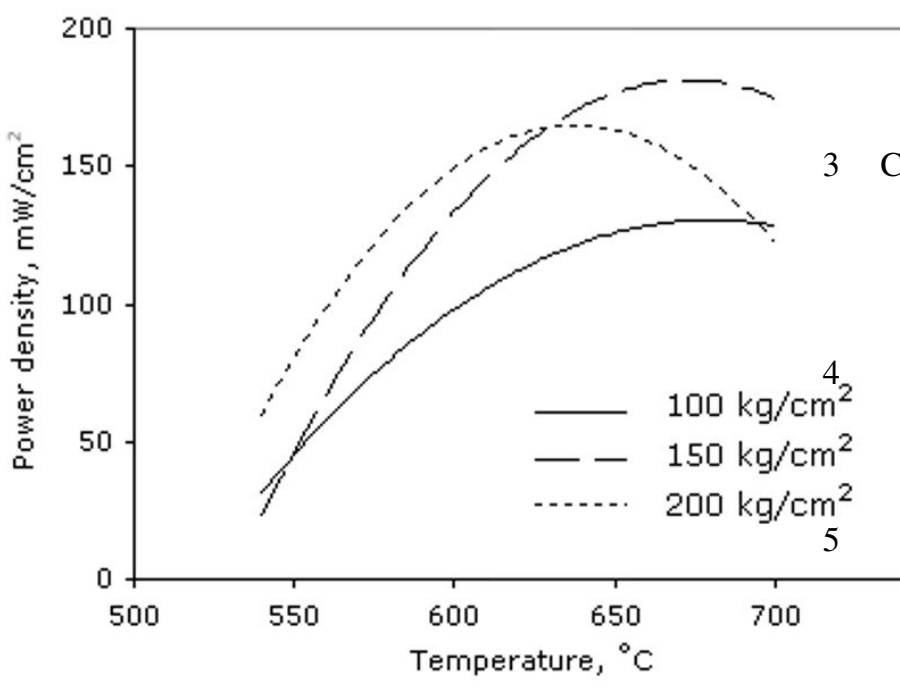

Fig. 5. Maximum power densities for different compaction pressure at varying cell operating temperatures.

\section{CONCLUSION}

The cells fabricated by dry-pressing method have performed well compared with the work done by other researchers in terms of power output. The method being cost effective and simple, the cells reached a maximum power density of $195 \mathrm{~mW} / \mathrm{cm}^{2}$, while operating at a temperature of $680^{\circ} \mathrm{C}$. The open circuit voltages were reasonably low due to the conductivities of the materials and were observed to vary with the operating temperature in the range of 650 to $900 \mathrm{mV}$ for temperatures ranging from 560 to $680^{\circ} \mathrm{C}$. The cells recorded the best performances at $650^{\circ} \mathrm{C}$ making it as intermediate temperature operations.

\section{ACKNOWLEDGEMENT}

Financial support for this work by the Swedish Research Council and SIDA is acknowledged. We are also grateful to each national programme for the projects in respective countries in this research and collaboration network project.

\section{REFERENCES}

1 T. Inagaki, F. Nishiwaki, J. Kanou, S. Yamasaki, K. Hosoi, T. Miyazawa, M. Yamada, N. Komada, Demonstration of high efficiency intermediate-temperature solid oxide fuel cell based on lanthanum gallate electrolyte, Journal of Alloys and Compounds, Volumes 408-412, (2006) 512-517.

2. Y. Kiros, X. R. Liu, B. Zhu, Cost-effective Perovskite for Intermediate Temperature Solid Oxide Fuel Cells (ITSOFC), Journal of New Materials for Electrochemical Systems 4 (2001) 253-258.

3 C. Lu, S. An, W.L. Worrell, J.M. Vohs, R.J. Gorte, Development of intermediate-temperature solid oxide fuel cells for direct utilization of hydrocarbon fuels, Solid State Ionics 175 (2004) 47-50.

S. Souza, S. J. Visco, L. C. Jonghe, Thin-film solid oxide fuel cell with high performance at low-temperature, Solid State Ionics, 98 (1997) 57-61.

D. R. McIlveen-Wright, B. C. Williams, J. T. McMullan, Wood gasification integrated with 7 friel cells, Renewable Energy, 19 (2000) 223228.

6 A.B.J. Oudhuis, A. Bos, J.P. Ouweltjes, G. Rietveld, A.B van der Giesen, High Efficiency Electricity and Products from Biomass and Waste; Experimental Results of Proof of Principle of Staged Gasification and Fuel Cells, The $2^{\text {nd }}$ World Conference and Technology Exhibition on Biomass for Energy, Industry and Climate Protection, Rome, Italy, 10-14 May 2004, 3-6.

7 S. Baron, N. Brandon, A. Atkinson, B. Steele, R. Rudkin, The impact of wood-derived gasification gases on Ni-CGO anodes in intermediate temperature solid oxide fuel cells, Journal of Power Sources 126 (2004) 58-66. 
B. Zhu, Advantages of intermediate temperature solid oxide fuel cells for tractionary applications, Journal of Power Sources 93 (2001) $82-86$. B. Zhu, X.T. Yang, J. Xu, Z.G. Zhu, S.J. Ji, M.T. Sun, J.C. Sun, Innovative low temperature SOFCs and advanced materials, Journal of Power Sources 118 (2003) 47-53.

10 T. Hatae, N. Kakuda, T. Taniyama, Y. Yamazaki, Low temperature preparation and performance of Ni/YSZ anode with a multilayered structure for SOFC, Journal of Power Sources 135 (2004) 25-28.

11 S.D. Kim, S.H. Hyun, J. Moon, J.H. Kim, R.H. Song, Fabrication and characterization of anodesupported electrolyte thin films for intermediate temperature solid oxide fuel cells, Journal of Power Sources 139 (2005) 67-72.

12 X. Xu, C. Xia, S. Huang, D. Peng, YSZ thin films deposited by spin-coating for IT-SOFCs, Ceramics International 31 (2005) 1061-1064.
13 D. Perednis, L. J. Gauckler, Solid oxide fuel cells with electrolytes prepared via spray pyrolysis, Solid State Ionics, 166 (2004) 229239.

14 D. Rotureau, J.-P. Viricelle, C. Pijolat, N. Caillol, M. Pijolat, Development of a planar SOFC device using screen-printing technology, Journal of the European Ceramic Society 25 (2005) 2633-2636.

15 C. Xia, M. Liu, Low-temperature SOFCs based on $\mathrm{Gd}_{0.1} \mathrm{Ce}_{0.9} \mathrm{O}_{1.95}$ fabricated by dry pressing, Solid State Ionics 1442001 249-255.

16 B. Zhu, S. Li, J. Sun, Q. Lin, $6^{\text {th }}$ European SOFC Forum, Ed. M. Mogensen, 2004, Vol. 1, p. 1062.

17 Z. Shao, S. M. Haile, A high-performance cathode for the next generation of solid-oxide fuel cells, Nature, 431 (2004) 170-173. 